\title{
PERAN ULAMA DALAM POLITIK
}

Yeti novita purnama sari

Emal : yetinovi@gmail.com

\section{Fakultas keguruan dan ilmu pendidikan Program studi pendidikan IPS Universitas lambung mangkurat Banjarmasin}

\begin{abstract}
Abstrak
Politik juga bisa dikatakan sebagai tentang legitimasi kekuasaan dalam hal Negara, dan juga merupakan suatu hal yang terlepas secara langsung dari yang namanya moralitas yang tercermin pada situasi konkrit Negara yang membutuhkan tindakan tersebut. Negara adalah sisi nyata dari perpolitikan, dengan itu maka untuk mempertahankan negara, pengabaian terhadap sifat sifat yang berbau moral dapat saja di hilangkan oleh seorang penguasa. Dalam berpolitik peran ulama sangatlah penting karena dapat mengontrol kebijakan penguasa dan menjadikan pihak penguasa dan pihak oposisi. Ulama di tekankan memiliki dua peran yang mana dianggap sangat penting, yang pertama, berdasarkan pada bobot keilmuanya maka para ulama sudah sepantasnya sebagai penncerah alam pemikiran umat. Yang kedua ada sebagai panutan umat dalam artian khusus dalam keteladanan moral yang di ajarkan dan di contohkan ulama kepada masyarakat.
\end{abstract}

\section{PENDAHULUAN}

Di Negara demokrasi modern ini, partai politik juga sering dianggap sebagai salah satu atribut Negara, partai politik ini sangat di perlukan kehadiranya bagi Negara khususnya di Indonesia yang merupakan Negara yang merdeka dan berdaulat.keseluruhan fungsi nya itu di wujudkan melalui pemilihan umum yang dilaksanakan secara demokrasi, jujur, adil, dengan mengadakan pemungutan suara secara langsung, umum, bebas dan rahasia oleh pihak yang bersangkutan. 
Dalam negara kita diharapkan melaksanakan demokrasi harus sesuai fungsinya dengan baik sehingga dapat menjadikan Negara kita ini suatu Negara yang demokratis, pada kenyataan nya di Negara kita ini masih belum memenuhi apa yang menjadi fungsi tersebut. Mengingat fungsi politik yang begitu penting sering bahkan keberadaan dan kinerjanya itu merupkan ukuran mutlak bagaimana demokrasi berkembang disuatu Negara. Meskipun itu bukan pelaksana dan suatu pemerintahan, namun keberadaanya akan itu mempengaruhi bagaimana dan arah mana pelaksanaan pemerintahan yang dijalankan.

Dalam penulisan Ini akan di paparkan bahwasanya mengapa ulama itu berperan bagi politik dalam kehidupan sosial yang mana ulama ini adalah figur dalam masyarakat dan menjadi tempat untuk konsultasi dalam bidang rohani dan dalam kehidupan yang profan termasuk dalam bidang politik, politik ini sendiri dimaknai secara bermacam macam presepsi oleh para ulama, namun demikian secara umum mereka itu memaknai dan memahami bahwa politik itu merupakan bagian yang tidak terpisah dari ajaran agama. Dalam kajian inilah banyak para ulama yang kemudian berkiprah pada dunia politik.

\section{PEMBAHASAN}

A. Pengertian politik dan ulama

Menurut Machivelli, politik ini merupakan bagaimana tentang legitimasi kekuasaan dalam hal Negara, dan juga merupakan suatu hal yang terlepas secara langsung dari yang namanya moralitas yang tercermin pada situasi konkrit Negara yang membutuhkan tindakan tersebut. Negara adalah sisi nyata dari perpolitikan, dengan itu maka untuk mempertahankan negara, pengabaian terhadap sifat sifat yang berbau moral dapat saja di hilangkan oleh seorang penguasa. (JELAHUT, 2017)

Politik menurut perspektif islam dengan mengutip dari pandangan gabriel Almond dan J.S coleman, muin salim yang berpendapat bahwa ada dua fungsi utama politik, yang mana ada fungsi masukan dan fungi keluaran, dan termasuk kedalam input punctions meliputi sosialisasi politik, rekruitmen politik, artikulasi, agregasi kepentingan pelaksanaan aturan aturan. Dari beberapa pengertian di atas dapat di simpulkan istilah politik berkaitan dengan kekuasaan dan penggunaanya, baik itu terbatas maupun dalam 
skala yang lebih besar dalam suatu Negara, bahkan dalam skala internasional dan meliputi bagaimna ia mengelola sesuai dengan aturan aturan yang telah di sepakati oleh masyarakat, Negara, antar Negara, dimana suatu politik itu di terapkan.

Pengertian ulama ini istilahnya sering di sebut sebagai orang orang yang memiliki ilmu ilmu agama, atau orang orang yang berilmu. Artinya setiap orang yang menganggap dirinya sebagai ulama maka dia harus memiliki ilmu agama yang bisa di sampaikan dan di jelaskan kepada masyarakat.

B. Peran ulama dalam politik.

Ulama yang mengiklaskan niat nya hanya untuk belajar ilmu islam dan menyebarkanya ke kalangan umat muslim tanpa mengharapkan keduniaanya yang di peroleh, ulma ini lah yang pantas mempunyai posisi penting dalam sebuah strategi di tengah tengah masyarakat. Maka menjadi kaum yang berada di tengah masyaratkat namun lebih tinggi posisinya di bandingkan dengan posisi seorang yang penting tersebut karena seorang ulama adalah penasehat, naasehat dan saran ulama akan selalu di perlukan oleh seorang pemimpin dalam berbagai permasalahaan. Dahulu juga sebuah kejayaan islam di bangun dari suatu pondasi islam pada masa daulah umayyah, abbasyiah dan sampai yang terakhir ottoman turki, khususnya Negara Indonesia untuk menjadi Negara yang republic Indonesia ini juga mendapat kesepakatan dari para ulama. Kalau ulama tidak hadir dalam ranah public maka yang akan terjadi konsekuensi dan merasa ada yang hilang, mengapa demikian? Karena ulama di ibaratkan pelita di dunia, yang menerangi atau penunjuk jalan yang benar juga penenang dalam kegelapan serta menjadi rujukan ketika kita dalam keadaan kebingungan. Ulama juga akan menjadi cahaya kelak di akhirat bagi yang mengikutinya, itulah fungsi ulama. Dalam berpolitik itu bisa di artikan sebagai mensiasati, bersiasat bagi umat maka hal itu sangatlah penting politik dalam dunia islam apabila dalam perpolitik tersebut dilakukan dengan semestinya agar menuju kejalan yang benar.

C. Peran ulama pada abad ke 13-19 dalam gerakan nasionalisme Indonesia Salah satu tokohnya adalah nuruddin Ar raniri, syeikh abdul rauf dan syeikh Arsyad al banjari yang mana ulama ini lah yang sudah melakukan gerakan gerakan nasionalisme 
walaupun pada saat itu masih berbentuk kerajaan yang ada di nusantara ini dan perpengaruh para perkembangan islam di nusantara.

1. Ulama Nurrudin ar raniri

Beliau merupakan ulama aceh nama asli beliau itu adalah Nur al-din Muhammad ibn, ali hasanji ibn Muhammad hamid ar-raniri al quraisy Asy-syafii. beliau berhasil memimpin ulama aceh menghancurkan ajaran tasawuf falsafiyah hamzah al fansuri yang mana pada ajaran tasawuf ini di khawatirkan dapat merusak aqidah islam yang awam terutama yang baru memeluk agama islam. Pemikiran beliau dalam politik itu di jelaskan dalam karangan beliau Bustan al shalatin, beiau mengungkapkan bagaimna beliau menasihati sultan dalam fungsinya sebagai penguasa dan khalifah tuhan di bumi. Dengan mengtip ayat alquran menjelaskan bahwa tanggung jawab dan kewajiban nya terhadap rakyat melindungi dan lemah serta mendatangkan kebaikan bagi rakyat akan membuat nya di lindungi dan dirahmati tuhan.

2. Ulama syeikh abdul rauf

Nama lengkap beliau adalah Aminuddin Abdurauf bin ali aljawi Fansuri as-singkil yang lahir di daerah singkil yang mana sekarang merupakan salah satu daerah aceh peran beliau sebagi qodi atau pemimpin yang adil di kesultanan aceh Darussalam sekaligus pengajar dan pengarang kitab. Beliau merupakan tokoh kunci dalam perkembangan islam terutama pada bidang tasawuf sebagai salah satu pendidikan pada aspek keruhanian di nusantara. Hampir semua silsilah tarekat shajariyah ini perpusat kepada dirinya dan melalui sejumlah muridnya, tarekat ini tersebar keberbagai wilayah di dunia melayu- nusantara.

3. Ulama syeikh arsyad al banjari

Metode dakwah beliau ini ada di bagi menjadi 3 yaitu: metode bil hal, metode bil lisan dan metode bil kitabah.

Pada metode bil hal, keteladanan yang baik yang di reflesikan dalam tingkah laku, gerak gerik dan tutur kata sehari hari dan juga di saksikan secara langsung oleh murid murid beliau. Pada metode bil lisan ini yaitu mengadakan pengajaran dan pengajian yang bisa di ikuti oleh siapa saja. Dan pada metode bil kitabah ini beliau menggunakan bakat yang dimiliki dalam bidang tulis menulis, sehingga lahirnya lewat ketajaman penanya kitab kitab yang menjadi pegangan umat, kitab karangan 
yang paling menumental adalah kitab sabilal muhtadin littafaquh fiddin yang mana kemasyurannya sampai ke Negara Malaysia, brunei dan pattani ( Thailand).

\section{Simpulan}

Dari pemaparan materi di atas dapat di simpulkan pula bahwasanya berpolitik itu erat kaitanya dengan ketatanegaraan bukan erat lagi akan tetapi merupakan cakupanya, dalam berpolitik juga ada peran ulama yang mana peran dan fungsinya ini sangat berpengaruh bagi seorang pemimpin khususnya di Indonesia. Sebuah petunjuk bagi pemimpin yang mengikuti ulama dan kepimimpinanya itu akan berdampak baik bagi masyarakatnya kareana ulama merupakan orang orang yang memiliki ilmu ilmu agama, atau orang orang yang berilmu. Artinya setiap orang yang menganggap dirinya sebagai ulama maka dia harus memiliki ilmu agama yang bisa di sampaikan dan di jelaskan kepada masyarakat.

Dari peran tersebut dapat juga di simpulkan bahwa peran ulama juga dapat mengontrol kebijakan penguasa dan menjadikan pihak penguasa dan pihak oposisi. Ulama di tekankan memiliki dua peran yang mana dianggap sangat penting, yang pertama, berdasarkan pada bobot keilmuanya maka para ulama sudah sepantasnya sebagai penncerah alam pemikiran umat. Yang kedua ada sebagai panutan umat dalam artian khusus dalam keteladanan moral yang di ajarkan dan di contohkan ulama kepada masyarakat.

\section{Referensi}

Jelahut, F. E., Jegalus, N., \& Kosat, O. FILSAFAT POLITIK NICCOLO MACHIAVELLI: SEBUAH KONSEP POLITIK TANPA MORALITASI NICCOLO MACHIAVELLI'S POLITICAL PHILOSOPHY: A CONCEPT OF POLITICAL THINKING WITHOUT MORALITY.

Diponegoro, A. M. (2016). Ulama Sebagai Kekuatan Politik: Peran Ulama Nahdlatul Ulama Dalam Kemenangan Ipong Muchlissoni Di Pilkada Langsung Kabupaten Ponorogo 2015 (Bachelor's thesis, Jakarta: Fakultas Ilmu Sosial Dan Ilmu Politik UIN Syarif Hidayatullah). 